\title{
An Alaskan Athabascan Technique For Overcoming Alcohol Abuse
}

\author{
ARTHUR E. HIPPLER ${ }^{1}$
}

\begin{abstract}
It is proposed that the basic tactics used by members of a distinct ethnic group to overcome alcohol abuse will be in part determined by culturally accepted methods of social control. These methods themselves will be based in large part upon the modal psychodynamic organization of members of that group. In the case presented the Athabascans of interior Alaska tend to overcome alcohol abuse by adhering to fundamentalist Christianity which reflects their need for an external superego; that in the past took the form of a nearly absolute chieftainship.
\end{abstract}

RÉSUMÉ. Une technique des Athapascans de l'Alaska pour surmonter l'abus d'alcool. L'auteur propose que les techniques de bases employées par les membres d'un groupe ethnique distinct pour surmonter l'abus d'alcool sont en partie déterminées par des méthodes culturellement acceptées de contrôle social. Ces méthodes elles-mêmes sont basées pour une large part sur l'organisation modale psychodynamique des membres du groupe. Dans le cas présenté ici, les Athapascans de l'Alaska intérieur tendent à surmonter l'abus d'alcool en adhérant à un christianisme "fondamentaliste" qui reflète leur besoin d'un superégo externe; dans le passé, ceci prenait la forme d'un rôle quasi absolu du chef.

РЕЗЮМЕ. Метод борзбы со злоупотреблениями алкоеолем у аляскинских aтапасков. Основная тактика, применяемая членами окружных әтнических групп для преодоления злоупотреблений алкоголем, должна определяться, среди прочего, методами общественного сдерживания, соответствующими местньм культурным традициям. Сами әти методы должжны в вначттельной степени основываться на модальной исиходинамической организации членов соответствующих групп. Рассматривается конкретный пример атапасков Внутренней Аляски, у которых борьба со злоупотреблениями алкоголем имеет тенденцию выливаться в приверженность $\kappa$ религии христианского фундаментализма, что также отражает их потребность в " высшем разуме ". В прошлом әта тендениция принимала форму почти неограниченного господства над Личностью.

\section{INTRODUCTION}

Kearney (1970) suggests that heavy drinkers among the Zapotec-Mestizo of Ixtepiji in Oaxaca, Mexico, tend to become converts to fundamentalist religions to help them stop their drinking since they fear the aggressive impulses which are released while they are drunk. I have noted a similar phenomenon among the Athabascan Indians of interior Alaska, and at least one other observer (Clairmont 1962) has noted the development of this kind of phenomenon among other northern Athabascans, those at Aklavik in Canada. Nonetheless I believe there are some additional dynamics at work.

It is proposed that at least for Athabascan Indians alcoholism is overcome by making use of fundamentalist Christianity as an externalized superego reminiscent of the traditional legal system now badly attenuated since contact with Euro-Americans.

\footnotetext{
1 Institute of Social, Economic and Government Research, University of Alaska, Fairbanks, U.S.A.
} 
The apparent similarity between fundamentalist Christianity and old Athabascan law seems to suggest that the underlying modal psychodynamics of this group may predispose them to certain kinds of techniques of social control. An investigation of culture, personality and social structure of these Indians may well shed light not only on their own but on other people's behaviour as they relate to alcoholic abuse and tactics for overcoming it.

In general, I propose that the tactics members of a given ethnic group use to overcome alcoholism will tend to flow from the basic assumptions about social control which are grounded in the basic personality of the group as well as reflecting the more generalized approaches which any alcoholic must take to overcome his addiction.

Among the more generalized approaches, the importance of using some ideology analogous to "religious fundamentalism" to assist the alcoholic in "drying out" has been intuitively obvious for some time. This tactic in fact provides the basis for Alcoholics Anonymous and other such groups.

The dynamics of these tactics centre around the notion that individual weakness (alcoholism) can be overcome by admitting unworthiness and subjecting the self first of all to a higher outside authority. Slowly the individual is expected to internalize this authority but never to be freed of the primitive "bad" impulses which lead him to alcoholism. He must always rely to some extent upon this external authority or its representatives for the rest of his life.

The specific form of this approach will, I believe, depend upon the nature of the group itself. To clarify what appear to be the dynamics in what is seen as the Athabascan approach to sobriety, a brief overview is given of some aspects of Athabascan life. The socialization procedures and some of the institutions for social control are especially dealt with because child-rearing and the resultant personality structure offer some insight into the reasons for alcoholic abuse and its specific behavioural accompaniments; also they indicate the substrates of strength which help the individual to overcome the problem. What appear to be some of the basic institutions that created social integration in the past, how they have been changed by acculturation pressures, and finally the reasons for the present use of fundamentalist Christianity as a tactic of control will then be discussed.

\section{ATHABASCAN CULTURE AND PERSONALITY}

The Athabascans of interior Alaska lived and still live in one of the harshest environments inhabited by humans on earth, with routine winter temperatures in the range of $-50^{\circ} \mathrm{F}$. to $-60^{\circ} \mathrm{F}$. Nearly devoid of reliable and abundant food resources, they lived in small isolated matrilineal family groups of 10 to 15 persons, widely separated from each other during the food-gathering and fur-trapping times of year, risking temporary village groupings of 60 to 100 persons only for about 4 months in winter, living off food which was cached in the summer and fall. If too many people lived in the same area for too long, they would all simply have starved. As it was, starvation was periodic and hunger endemic. (See Hippler 1973 for a fuller discussion.) 
The early childhood socialization procedures for aboriginal Alaskan Athabascans are poorly reported, but by using the limited ethnographic record (i.e., McKennan 1959, Osgood 1936) added to my own observations and a psychodynamic folklore analysis, it is assumed with Kluckhohn (1942) and Dundes (1965) that unconscious dynamics are expressed in the folklore of a group in a nonanxious fashion. The childhood socialization is believed to have been generally as follows.

The Athabascan mother tended to be matter-of-fact about her children extending adequate but not very overtly warm or emotionally gratifying care. It is postulated that, faced with what was probably an 80 per cent infant mortality in aboriginal times, mothers tended to develop a defensive non-involvement with the infant who might so quickly be taken from her by starvation. This phenomenon has been noted among southern Athabascans as well by Boyer (1962). In addition, this mother herself was very likely the product of a child rearing which left her jealous of infants, with a tendency towards oral aggressiveness, yet being an emotional isolate for reasons pointed out below. Furthermore, she had learned to control her emotional expressions, finding them fraught with danger. Briefly, unconscious forces and the reality of the child's possible death from starvation combined to cause her to be perceived by the infant as rather cold, distant and non-nurturant. Such perceptions are, I believe, significant in developing the combination of oral longings, cross sex anxiety, and aggressive impulses which are commonly associated with alcoholic abuse.

Three critical factors apparently came together in the early life of a "typical" Athabascan infant which had implications for its entire psychosexual development and ultimately for the nature of the tactics used to overcome alcoholism. The use of the term "typical" here does not suggest that some invariant "cookie cutter" model of culture is proposed. Nonetheless, perhaps too much has been made of the need to observe variance and avoid the dangers of the "unimodal" personality model. There has been such essential agreement among Athabascans on details of their life as to suggest that at least the behavioural framework within which potentially variant personalities might operate acted as a restraining influence at the very least, and certainly tended to mold various personalities into similar overt behaviours. These three factors were 1) the fact of hunger which was real and endemic, 2) the inevitable death of younger siblings year after year, and 3) the essential, perceived "coldness" of mother.

For the nursing infant, hunger resulting from a decrease in the food supply of the group is not as immediate as for slightly older children and aged adults. But if mother can become so starved as to be producing either little or nutritionally inadequate milk, the infant, even if it is not doomed by this lack, will feel that it is not properly nourished and will also perceive the hunger of the mother. Owing to his archaic emotional organization, the infant may well feel an increase in talion anxiety about being devoured by the mother, a process described by Freud (1915) and Klein (1948). If the infant lives through such an experience, its unconscious memory will certainly have influenced his perception of the world.

Additionally, as the mother's milk becomes thinner and her irritability increases, the infant will probably never feel emotionally or physically satisfied. Greenacre 
(1952) notes that since this occurs at an age when ego and other controls have been poorly differentiated, the individual will grow to adulthood with a continual feeling of diffuse anxiety. Its irritability may be responded to either by a lack of attention, or even more irritability on the part of the mother. Even if she should try to make up for the deteriorating situation by greater attention, it will very likely only increase the infant's talion anxiety and guilt to watch her struggles, since the infant's omnipotent fantasies will make it believe that it has caused this pain.

At the very least the infant who lived would probably come to have deep oral longings and anxieties about these longings. It would also tend to have confused feelings of guilt and anger towards its mother, probably intensified by the death of younger siblings which also created additional problems. The nurturant attention which the mother gave to the baby, however inadequate it might have been, would probably produce intense feelings of jealousy and even murderous rage in the older child directed both at the baby and ambivalently at the mother. If the baby should die, and it usually did, the young child most likely felt a deep sense of guilt over the death plus a heightening of terrifying feelings of omnipotence, which would probably result in a belief that uncontrolled emotions are dangerous indeed. The child then probably developed not only guilt concerning the infant's death, but also a fear of his uncontrollable wish impulses and, as an adult, a corresponding need for the emotional controls he had so poorly internalized.

Additionally, the child, especially if a girl, was usually given the duty of helping to care for the baby, thus being forced into the position of adopting the maternal position towards its hated young rival. The older child then tended towards oversolicitousness as a defensive posture, and inevitably the youngest child and in fact all the younger living children were in turn "spoiled", further weakening their internal controls, and increasing the need for external controls as an adult. This tended at one and the same time to heighten dependency cravings, and to increase the guilt which accompanied them. It also increased feelings of omnipotence yet also heightened the anxieties which accompanied those feelings. Together, such pathic concerns appear to have developed a precariously defended oral dependent and oral aggressive personality with a tendency to project guilt, all of which it is believed are associated both with drinking patterns and tactics used to overcome them.

In addition to these basic oral concerns, some of which are very common to the alcoholic-prone personality as noted below, other dimensions of the ego-defence system give further insight into the form of adult coping mechanisms currently associated with the rejection of alcoholism.

The mother's perceived coldness can only be interpreted in limited ways by a child. The child may split the mother and the maternal introject into the "good" (nurturant-present) and the "bad" (absent, non-nurturant) mother. It may project this "bad" maternal introject out onto the universe at large, investing the universe with demons, but finally it tends, almost inevitably as a child must, to reintroject such demons because of their basic grounding in the personality (Freud 1923) which make it difficult to get rid of a feeling of interior "badness".

For Athabascans, the demons are very real. Most of the Athabascans of any 
age whom I have met appear to be convinced that the universe is populated with a variety of demons some of which steal children, apparently reflecting both what is wished for the younger sibling and fears for the self. Others in this demonic pantheon have sharp teeth and bite, probably representing talion anxieties concerning oral aggression towards the mother and fears of her incorporating him as Lewin (1950) suggests, or are vague, shadowy ghosts who are dangerous in some unclear way (possibly representing free floating anxiety or guilt about death wishes directed towards parents and siblings).

The child may also interpret its mother's "coldness" as due not to some defect in the mother but an inadequacy in the self. This unacceptable "bad self" will also be projected; but, both as a projection and as a reintroject, it will provide a fearful and hostile emotional environment for the child.

This process, though it bears in common processes which occur in all children, appears to have had and still to have a special intensity among the Athabascans buttressed as it was by reality factors (continuous hunger and fear of war) and by social institutions (folklore which stressed anxious themes such as those noted above). The child, at the minimum, then grew to adulthood with deeply ambivalent feelings towards the mother, as well as unsatisfied oral needs which became fused with aggressive instincts and murderous impulses. It learned to defend itself against these feelings by a massive expenditure of emotional energy directed towards the control of emotional expression. Finally, through the process of being "spoiled", its superego was weakened to the point that internal controls were difficult to achieve while the superego still retained a punitive character. The Athabascan Indian rebelled against these controls and periodically became moody, angry, depressed, and either exploded or tried to avoid people, and finally came to rely in large part on external authority.

To add to this, the often absent father, who in aboriginal times spent much of his time in the men's house and until very recently was often hunting or trapping, and who additionally belonged to his mother's clan, not the child's, probably made the resolution of oedipal conflicts more difficult. Even before that, however, very early pressures for toilet training must have exacerbated already strong feelings of maternal rejection. Presenting feces to mother as a gift never worked. There was nothing one could seem to do to warm this cold person.

Therefore, with the father absent and the child continually in the mother's company, often sleeping in her bed or at least near her, the boy at least must have experienced serious anxieties about sexual controls when he did feel he was in danger of "warming" his mother (in a sexual sense). Present-day actions of many Athabascan men commonly include Don Juan-like womanizing, group sexual activity and the need to drink heavily before attempting sexual intercourse. These actions tend to suggest the presence of cross sex anxiety such as is found in other groups with similar socialization patterns (Hippler 1969, 1970; Burton and Whiting 1961). These anxieties in turn were made more severe by the very rigorous taboos on premarital sexuality. Violating such taboos was punished in part by making the offender ineligible as a good hunting or trading partner. This probably re-elicited concerns which fused anal and sexual instincts, with which the Raven tale cycle in Athabascan folklore is replete. 
Generally then, one can see an adult Athabascan Indian as having had to cope with an additional element of self-hate, through his early toilet training, and increased anger at this stern, socializing mother over and above that derived from his earliest experiences. Finally, he would come even to view sexuality as dangerous, as his initially desired object would be the unconsciously enticing but oral devouring vagina dentata mother, and these fears would be strengthened by a general sex taboo which would convince him of the essential danger of women. The mythology, for example, is replete with overt, not merely symbolic, dentate vaginas. They actually chew off penes; in one case, the villainess made a rope of such penes. She could only be overcome by ramming a burning four-foot $\log$ into her rapidly chewing vagina which had destroyed smaller logs. There is more than a hint of the penis being seen in this myth as a defensive weapon against women, a viewpoint supported by the violence between adult men and women nearly ubiquitous at present.

\section{INSTITUTIONAL SUPPORTS FOR ATHABASCAN PERSONALITY}

The fearful, lonely, angry and nearly paranoic adult personality which might have resulted from the kind of socialization I have noted above, however, was creatively integrated personally as well as socially through two very important institutional processes: the traditional legal system and the gift and reciprocal obligation systems. The difficult introjects were handled by the individual by projecting them as varied demons onto the world at large, and the aggressive and hostile impulses were handled socially by allowing them to be channelled within a highly structured authority system, an important aspect of which was the clan.

\section{The reciprocal exchange system}

This matrilineal society's clans were organized into a moiety system. Individual clans within these moieties exchanged wives with clans in the other moiety with cross-cousin marriage the preferred form. The need to control and balance the world was expressed in the ubiquitous exchange systems between matri-clans which kept everything "even", that is, wealth was redistributed and thereby tensions were reduced.

This system of "potlatch" exchanges worked as follows (Hippler et al. in press.). On the death of a matrilineal kinsman, members of the opposite moiety had to be called in to handle the body which was tabooed as dangerous for matrilineal kinsmen to touch. Their fear of the angry ghost of the deceased, probably a projection of guilt associated with the kinds of tensions noted above, meant that death duties could only be undertaken by someone unrelated in the Athabascan sense and therefore not subject to the ghost's anger.

Payments for this duty took the form of extensive gift-giving at a huge party in which one matriline, often in conjunction with others in its moiety presented gifts to another in the opposite moiety. In this way they both paid off their debt and associated themselves with another group even more intensely than by the marital exchanges which already bound them.

Additionally, the potlatch provided a technique for escalating reciprocal exchanges and thereby furthered the political power of the headmen of a clan. 
By subtle manipulation of the amounts to be given to different individuals, animosity as well as amity could be expressed, thereby allowing an outlet for aggressive as well as affiliation needs.

Moreover, this system provided the basis for alliances between groups both to provide for and protect the somewhat brittle system of social controls which rested ostensibly on an authoritarian chief, but in fact depended upon consensual validation by clan heads in a local band.

The potlatch then was a creative expression of dependency needs, projected guilts and fears, aggressive urges and the need to develop a base for external controls as expressed in the legal system.

\section{The legal system}

The resolution of conflicts and disputes in aboriginal Athabascan society (the legal system) was based upon three primary assumptions which were apparently uniform for nearly all Athabascans (Hippler and Conn 1972):

1) Authority was absolute.

2) To be called before the absolute authority for wrongdoing implied guilt.

3) One was called before this absolute authority solely for the purpose of determining punishment or reconciliation which were very dependent upon the state of repentance of the wrongdoer and his position in society.

These suggest prevalence of a very punitive guilt and the need for external controls for Athabascans. The chief, as noted before, was the final authority. Nonetheless, if it was felt that the chief was in the process of making a poor judgement, the subchief, who might be approached on the matter by one of the lineage heads, would openly state his disagreement in council. In reality, at this point, the chief had to conclude that more deliberation was necessary. That is, if someone brooked his judgement in council, they would only do so for extremely important reasons. A chief who would ignore such a clear signal would soon find himself with a reputation for being "hasty". Such a reputation was hard to overcome and struck directly at Athabascan fears of losing control, and men strove to avoid being so labelled. Furthermore, angering a powerful clan could lead to war; this added pressure to the already existing tendency towards long and careful deliberation. Again, I believe, this expressed the need for control of aggressive impulses and a fear of their release.

Theft and adultery were two of the three most important criminal activities with which Athabascan law had to contend. In both cases, the grave fear was that irreparable damage might be done to the precariously balanced inter-clan relationships. Without detailing the deliberative proceedings here, it might be noted that sanctions such as banishment or the death penalty were only imposed upon a general consensus of all clan heads, offended and offending alike. This suggests that though punishment may have been what was desired, the social disruptive results of precipitate punishment were very grave, especially in the case of murder. The primary resolution of these malefactions was through restitution and payment of damages to the victim.

Murder was, of course, the most serious of crimes, and it could be punished 
by death or banishment. But there were various ways in which this problem might be handled. The complainants in a murder case were usually the matrilineal kinsmen of the victim. The task of the chief in such a case was either to get the kinsmen of the victim to accept a death payment from the killer, or to get the kinsmen of the killer to agree that the killer himself should be executed. If the matriline of the victim, after a hearing at which the murderer and various witnesses, if any were heard, were convinced that a death payment (weregild) should be accepted, the matter ended there. Such an outcome would result if it was felt either that the victim had provoked the attack or that he had been of much lesser importance than his killer. Among the considerations involved would be the importance and size of the killer's matriline. Even if they would accept the death penalty for one of their number, they might become unfriendly to the complainant group. In this event, a tension and imbalance in the mutual expectations and obligations might prove disastrous for the group; decreased cooperation could mean starvation and war.

If the victim's matriline demanded the death penalty and the chief concurred, the murderer was killed. Should he attempt to flee, he would be considered a fugitive and fair game for anyone who killed him. This "outlawry", of course, permitted the expression of aggressive urges.

The most serious complications occurred when a "good" man (influential, well thought of, and from a powerful family) murdered a man of similar stature. In such a case, if the offended matriline would not accept a death payment there was usually no way for a death penalty to be imposed. The offended matriline would feel it could not ask for the death of a "good" man, and the offending matriline would not willingly acquiesce in the capital punishment of one of their luminaries.

At such an impasse, all parties knew that war was impending. The offended matriline would contact all of its major family heads in all of the surrounding villages. Discussion would continue intermittently for up to 5 years to determine whether or not war should be initiated. Such a process realistically could only occur when the offender and his victim were not only from different clans but different bands (villages). Some solution short of war would be found for intravillage murder. If no solution for intra-village murder could be found, it could lead to the splitting of a village and hence also to war.

The terror concerning war was based on the recognition that there was no adjudicative procedure for ending it. Furthermore, in an attack on an enemy camp, one might also kill one's own relatives or alternatively they might be slaughtered as potential fifth columnists by their non-kin neighbours.

Moreover, since no war ever ended, and since stealth was the chief characteristic of a raid, any stranger seen approaching might be an advanced scout of a war party, or an individual avenging an ancient forgotten wrong done to his great grand-parental matriline.

Thus, not only did Athabascans fear the demons and ghosts of the universe with which they ubiquitously populated the forest, but in reality had to fear the danger of physical attack by all human strangers. Consequently, strangers were put to death if they could not account properly for themselves or identify without confusion their genealogical ties. 
It may be noted that one of the most important functions of the legal system was essentially to protect the group from fission as well as other negative results of the suspicious and somewhat violent attitudes which matrilines held towards each other. This was always done in the constant fear of what might occur if controls broke down.

The crucial issues here were that controls were powerful, external, legitimate and absolute but, though punishment depended in part upon repentance, one must always balance off and pay for misdeeds. This situation changed under the pressure of contact with Euro-Americans, and those changes seriously weakened the structural supports for Athabascan personality leading to social disintegration and hence, in part, to the personal disorganization of alcohol abuse.

\section{THE EFFECT OF CULTURE CHANGE}

The interior Athabascans for the most part were contacted and missionized by Roman Catholic (Yukon River), Russian Orthodox (mostly among the TanainaKenaitsie and Ingalik), and Anglican missionaries (Upper Yukon and Tanana Rivers). Both the Roman Catholic and Anglican missionaries tended to present their religious convictions as loving and paternal. That is, Athabascan Indians were taught that God was beneficient and forgiving, most of all forgiving. His law was not harsh and implacable and the demonology of Catholicism and Anglicanism was and is pale indeed by Athabascan standards. Russian Orthodox influence declined rapidly after the mid 1800s. It appears since that time to have functioned similarly to Roman Catholicism and Anglicanism. By itself, this had little direct impact upon traditional laws, but in conjunction with other changes proved an extraordinary problem for Athabascan moral concepts.

When heavy drinking of alcoholic beverages began to be the norm by Athabascan Indians, in most cases after the turn of the twentieth century owing to late contact with whites, anti-social activity attendant upon this drinking expanded nearly asymptotically. As Horton (1943) noted, among primitive groups where heavy drinking is the norm, it seemed to result from anxieties about food scarcity among other causes, although new anxieties were created by drinking. It would appear for Athabascans that both the food anxiety (and the fantasies of a nonloving mother) and the lack of stable social controls are operative.

Specifically, the aboriginal legal system securely able to deliberate perhaps one or two cases per village per year became so overloaded with problems of adultery, theft, violence and murder as a result of alcohol abuse that it completely broke down. Furthermore, with the advent of white law, chiefs could not have recourse to the death penalty any longer which further weakened their power as its constant threat was considered a true deterrent to crime. This was a crushing blow to the Athabascan legal system, as was the collapse of the possibility of deliberation.

Finally, the advent of Euro-American power meant that there was the possibility for opportunists to be selected as local leaders. That is, men who might have little traditional right to the chieftainship became putative chiefs because of their ability to relate to whites. Such a state of affairs not only reduced the moral legitimacy of the chieftainship, but also exacerbated old inter-clan rivalries and released distrust and hostility. 
Mandelbaum (1965) in discussing heavy drinking among the Camba of the Andes states that one reason for their heavy drinking appears to be that "each person's social relations are marked by a profound sense of distrust of others and a lack of confidence in his own ability to control the outcome of a given episode of interaction". Though the cultures of interior Alaska Athabascans and the Camba appear to be superficially quite different, this also apparently refiects Athabascan dynamics.

Heavy drinking, which is uniformly believed by Athabascans to have been the central reason for the present deterioration of the family and of social controls, seems also to have been in part grounded in the character formation which existed in aboriginal times. But both the tendency towards excessive and explosive behaviour and infantile dependence were kept in check by the old institutions and the values which supported them. Strong controls on emotional expression were inculcated in the child and supported by adult expectations. Curbs on anti-social behaviour were provided by one's own matriline and by an absolute chief. Dependency needs were negated by rewarding hard work and nurturant and manipulative attitudes in the potlatch.

Malmquist (1968) states that both trust and confidence are necessary as a groundwork for moral controls. When these are not provided, the child needs external controls since his own are weak. This also seems to reflect the conditions of Athabascan life briefly recapitulated here. The once strong external controls collapsed under changes in the social structure, and the advent of alcohol appears to have provided a catalyst for the expression of anti-social and personally destructive acts.

Finally during this period, a generation of Athabascan Indians had grown to maturity who, though they believed in monsters and demons, were less afraid of what their projected monsters would do to them for misdeeds than were their parents since they were exposed to a more forgiving religion (Hippler 1972). Furthermore, there was no strong external control in the form of a chief. At the same time, all the old angry frustrated paranoid reactions could be called forth in alcoholic rages. The result was, it seems, nearly total social collapse especially in the area of normative controls.

\section{ALCOHOLISM AND ATHABASCAN PERSONALITY}

If our observations are correct, then the reason for this heavy drinking was at least in part embedded in the kind of personality which Athabascans shared and in part due to changes in institutional supports for that personality. As an example, Abraham (1926) notes that alcohol for men is a valuable adjunct to sexual congress since it dispels the disgust concerning women's genitalia which is a manifestation of the repression of homosexual tendencies.

My own observations of contemporary Athabascans suggest that many adult males are only able to initiate sexual activity with their wives after heavy drinking and in many cases after the men severely beat their wives. Apparently, women are viewed as sexually dangerous, a notion congruent both with the extensive vagina dentata motifs in the folklore and with pre-marital instruction to boys. Boys were 
and sometimes still are warned by adult males that female genitalia are "unclean", and that it is a rare woman with a "clean" (not disgusting) vagina.

Furthermore, Athabascans tend towards unisexual groupings. Men appear to feel much more comfortable in the presence of other men than in the presence of women. Traditionally, Athabascans viewed the household as belonging to the woman. The husband, from another clan, was really raising children for his wife's clan, and felt insecure around her relatives. His reward for marriage and overcoming his fear of women was that he could thereby develop ramified ties with other clans, increasing his power, wealth and prestige.

Hamer (1965) suggests that heavy drinking and the need for guardian spirits (a need only partly fulfilled in aboriginal Athabascan life) reflects exacerbated dependency needs resulting from poor primary relations. It seems as though primary relationships in the Athabascan nuclear family were indeed "poor" in this sense, and certain specific behaviours seem to bear this out.

For example, Athabascans apparently greatly fear owls because of their threatening eyes. Peto (1969) suggests that threatening eyes are the projection of the "red glow" of parental eyes, a repressive forerunner of the superego and an expression of body destruction fears. He further states that this appears to reflect a lack of even the most primitive ego-splitting defence. It is suggested that the fantasy and realities of the early socialization experience for Athabascans might well have exacerbated body destruction anxieties.

Wittkower and Weidman (1968) have noted that for magical thinking to continue into adult life there must be a significant fixation at early stages of development. The strong tendency for Athabascans to believe in ghosts and a wide variety of fearful projections has already been noted; thus there was a tendency for the continuation of magical thinking in adult life, which also supports the notion of the use of oral regression in the form of alcoholism.

Another aspect of contemporary Athabascan life is a tendency in some communities both for gang rape and for widespread wife-swapping at drunken orgies. Bok (1968) notes that group sex tends to be a perversion which is defensive against a "phallic mother" and an almost negligible father, both of which we can find in Athabascan life. In fact, Bok notes that acting out is inherent in the perverse character. It is both a search for punishment and a denial of the consequences of the act.

As Adler (1941) states, one aspect of alcoholism is the desire to escape from challenge and possible defeat. Thus the alcoholic is either unwilling or unable to assume duties and obligations, and protects himself through the formula of becoming a victim of what he regards as a serious addiction which absolves him of all responsibilities. The alcoholic is exclusively interested in himself, expects appreciation for a task before he has performed it, and professes deep concern for others, particularly the members of his own family; but unfortunately his addiction to drink prevents him from performing his duties. This again very clearly reflects both the behaviour and defensive explanations for it which are common among present day Athabascans.

This description is nearly a capsule caricature of the self-description and self-analysis young Athabascan men proffer for their inadequacy. Traditionally 
Athabascan males were not considered men till they were over 30 years of age by which time, under close supervision of their elders, they had attained hunting skills, given potlatches and otherwise proved themselves worthy (or had not). Now, with very few roads for adult validation available and no strong authority to direct them, but with the same combination of a fearful but weakened and spoiled superego, these young men find it difficult to avoid an infantile response and tend to drink heavily and do little else.

On the other hand, sociostructural factors also appear to have had an important impact upon this personality structure. As Spindler (1961) noted in discussing peyotism among the Menomini, the transitional groups to whom the wealth, position and accoutrements of contemporary white society were only marginally available, showed the greatest personal disorganization on the Rorschach test. The peyotists, who had actually integrated a new religion which we suspect functioned much like the fundamentalist religions for Athabascans, showed much greater personal integration.

Finally, Athabascans do not view their drinking as benign. This seems to reflect Simmons (1960) testing of Ullman's 1958 hypothesis that where there is ambivalence in the community about drinking (here expressed by the disapproval of Athabascan elders) the drinking can quickly become pathological and truly alcoholic in nature. In fact, Athabascans of all ages seem to see heavy drinking as potentially destructive of social values, and as Lemert (1962) points out, this is a clear indication that the behaviour is not integrated and thus is very likely personally pathological.

The kind of character who would respond in the above manner, I may suggest, very likely would also tend to rely strongly on external authority, the breakdown of which would leave him with few internal resources for control. Boyer (1964) in studying alcoholism among the Mescalero Apaches (and Athabascan) also finds that the old social structural techniques which permitted both the discharge of hostility and anxieties has, by its collapse, exacerbated problems of social control there, much as we note for interior Alaska. Graves (1967) has noted a similar phenomenon of the collapse of social controls in the southwest United States, as does Lemert $(1962,1964)$. Moreover, Hartman (1969) suggests that drug use, and we extend her meaning to alcohol abuse, reflects an early omnipotent narcissism which was wounded and is restored by drug use which turns the individual from genital sex to a form of autoerotic behaviour. This seems to conform rather closely to the estimate of what has happened to the Athabascan infant in the past.

\section{THE PRESENT SITUATION}

Yet faced with all this, within 30 or so years after 1900 and increasingly within the last 10 years, numbers of Indians found their way to more productive integrated lives by abandoning alcohol. The vehicle they have used is fundamentalist Christianity.

As has been shown, Athabascans need external controls. Furthermore, they expect such controls to be legitimate, stern and uncompromising though fair and 
deliberative. Those Athabascans whom I have observed to have successfully overcome alcoholic dependency appear to have done so either by reinterpreting high church Christianity in fundamentalist terms or by actually converting to fundamentalist Christianity. The religious content nearly uniformly expressed by the "Christian" converts stresses hard work, sobriety and faith in the redemptive and also punitive power of God. Fundamentalist beliefs are absolutist and authoritarian and hence well-suited to Athabascans. Paradoxically then, Athabascans can apparently best deal with certain aspects of change by going back to social control systems similar to the more traditional Athabascan notions.

Characteristically, conversion away from alcoholic dependency occurs as a result of a family tragedy or death (not necessarily alcohol-related) about which the individual develops strong guilt feelings. In many cases conversion is also the result of a vision. The contents of the visions reported range from fearful to neutral, but we assume some degree of covert fearfulness in nearly all of them based on associations to them which have been elicited here.

Certainly deaths of relatives, which are ubiquitous in Athabascan villages from trauma and disease, must elicit deep anxieties which result from fantasized guilt concerning such deaths. Because of the breakdown of traditional techniques for guilt alleviation, i.e., the traditional legal system and the potlatch, many Athabascans have turned towards fundamentalist brands of Christianity.

In brief, in every Athabascan village for which I have information ( 9 of which have either been formally studied or for which there is detailed information), the pattern has been the same. The most economically-capable late-middle-aged male is a reformed drunk and a quasi-fundamentalist.

One can only speculate as to the reasons for the age of conversion. Since traditionally Athabascan men were not truly granted adult status till they were 30 or more, there may be a cultural predisposition for late emotional maturation. However, perhaps more important might be the reduction in aggressive and sexual urges and consequent reduction in the need for defensive postures such as drinking.

But the function of fundamentalist Christianity seems clear. It provides a stern unbending code which threatens hellfire as punishment for offences. It is presented in terms which do not permit argument for or appeal, and it permits the individual to mobilize guilt feelings creatively by projecting evil onto the universe (the alcohol and alcohol drinkers). It also demands a period of many years of redemptive activity before one is completely accepted as "converted". It appears also that fundamentalist Christianity stresses individual responsibility and yet permits a massive defence of projection.

Since fundamentalist Christianity contains a rigid authoritarianism, the individual is encouraged to submit to religious authority. Belief in the devil as the antithesis to God merely supplements and supports traditional Athabascan belief in a system of demons and projected monsters. Thus the individual can believe he is free to choose within the terrible constraints of the chief's authority or that of the Church and can blame failure on the devil as he did upon projected demons in the past. The system seems admirably suited to Athabascan needs and recapitulates older Athabascan folk law ways, themselves apparently related to psychodynamic organization resulting from the socialization experience. 
It would therefore appear that the complex of intra-psychic tensions in Athabascan life was once integrated into a belief system characterized by the projection of demons onto the universe, personal isolation and loneliness. These concerns which were in part alleviated by a strong web of interlocking responsibilities and obligations were badly damaged by culture change.

Where strong external authority based upon a sophisticated recognition of the power of guilt feelings and redemptive behaviour once protected Athabascans against their angers and poor internal controls, there is now virtually no legitimate authority. Where once even decisions about sexual contact (marriage) were made by elders, which helped to reduce sexual anxiety for the individual, arranged marriages have all but disappeared.

I would suggest that changes in the social structure and consequently in the nature of the interpersonal relations in the presence of alcohol which could further dissolve controls has all but destroyed the traditional Athabascan system which integrated pathic attitudes into socially useful behaviour. Faced with this it seems somewhat clearer why many Athabascans might turn to an organization of controls structurally and psychically similar to the one they had in aboriginal times. It would appear that this is the reason for contemporary Athabascans making use of fundamentalist Christianity to control such behaviour as alcohol abuse.

\section{ACKNOWLEDGEMENTS}

The field work on which this paper is based was undertaken intermittently from June 1970 to April 1972 in various Alaska Athabascan communities. It was funded in part by National Science Foundation Grant GS 3026 and in part by the Institute of Social, Economic and Government Research, University of Alaska, Fairbanks.

\section{REFERENCES}

ABRAHAM, C. 1926. The psychological relations between sexuality and alcoholism. International Journal of Psychoanalysis, 7:2.

ADLER, A. 1941. The individual psychology of alcoholic patients. Journal of Psychopathology, 3: 74-77.

BOK, R. C. 1968. The phallic woman: The ubiquitous fantasy in perversions. Psychoanalytic Study of the Child, 23: 15-36.

BOYER, L. B. 1964. Psychological problems of a group of Apache: Alcoholic hallucinosis and latent homosexuality among typical men. In: W. Muensterberger and S. Axelrad (eds.) The Psychoanalytic Study of Society, Vol. 3. New York: International Universities Press, pp. 203-77.

BOYER, R. 1962. Social structure and socialization among the Apache of the Mexcalero Indian reservation. $\mathrm{Ph}, \mathrm{D}$. Dissertation, University of California (Berkeley).

BURTON, R. and J. W. M. Whiting. 1961. The absent father and cross-sex identity. Merrill Palmer Quarterly, 7: 85-99.

ClAIRMONT, D. H. J. 1962. Notes on the Drinking Behavior of the Eskimos and Indians in the Aklavik Area. Ottawa: Northern Coordination and Research Centre. pp. 62-64.

Dundes, A. 1965. The Study of Folklore. Englewood Cliffs, New Jersey: Prentice Hall. pp. 53-56.

FReUd, s. 1915. The Unconscious. Standard Edition. 1957. London: Hogarth Press, 14: 159-95. 
19: 3-68.

1923. The Ego and the Id. Standard Edition. 1961. London: Hogarth Press,

GRAVES, T. D. 1967. Acculturation access and alcohol in a tri-ethnic community. American Anthropologist, 69: 306-21.

GREENACRE, P. 1952. The Predisposition to Anxiety in Trauma Growth and Personality. New York: Norton, pp. 27-52.

HAMER, J. H. 1965. Acculturation stress and the function of alcohol among the forest Potawotami. Quarterly Journal of Studies on Alcohol, 26: 285-302.

HARTMAN, D. 1969. A study of drug taking in adolescents. Psychoanalytic Study of the Child, 24: 384-98.

HIPPLER, A. E. 1969. Popular art styles in Mariachi festivals. American Imago, 26(2): 167-81. pp. 56-63. 1970. The game of black and white at Hunter's Point. Transaction, April,

1972. Review of J. J. and I. Honigmann's Arctic Townsmen: Ethnic Background and Modernization. In: American Anthropologist, 74(4): 892-93.

1973. The Athabascans of Interior Alaska: A culture and personality perspective. American Anthropologist, 75(5): 1529-41.

HIPPLER, A. E., L. B. BOYER and R. M. BOYER. In press. The psychocultural significance of the Alaska Athabascan potlatch ceremony. Psychoanalytic Study of Society.

HIPPLER, A. E. and S. CONN. 1972. Traditional Athabascan law ways and their relationship to contemporary problems of "Bush Justice". Institute of Social, Economic and Government Research, Occasional Papers \#7. 19 pp.

HORTON, D. 1943. The function of alcohol in primitive societies: A cross cultural study. Quarterly Journal for the Study of Alcohol, 4: 199-320.

KEARNEY, M. 1970. Drunkenness and religious conversion in a Mexican village. Quarterly Journal of Studies on Alcohol, 31(1): 132-52.

KLEIN, M. 1948. Contributions to Psychoanalysis. The International Psycho-Analytic Library \#34. Hogarth Press. pp. 13-67.

KLUCKнонN, c. 1942. Myths and rituals: A general theory. Harvard Theological Review, 35. 45-80.

LEMERT, E. M. 1962. Alcohol values and social control. In: D. J. Pitman and C. R. Snyder (eds.). Society, Culture and Drinking Patterns. New York: John Wiley. 616 pp.

- 1964. Forms and Pathology of drinking in three Polynesian societies. American Anthropologist, (612): 361-74.

LEWIN, B. D. 1950. The Psychoanalysis of Elation. New York: Norton. 200 pp.

MCKenNaN, R. A. 1959. The Upper Tanana Indians. Yale University Publications in Anthropology, Vol. 55. New Haven: Yale University Press. pp. 117, 140-47.

MalmQuist, C. P. 1968. Conscience development. Psychoanalytical Study of the Child, 23:301-31.

mandelbaum, D. G. 1965. Alcohol and culture. Current Anthropology, 6: 281-88.

osgood, c. 1936. Contribution to the Ethnography of the Kutchin. Yale University Publications in Anthropology, Vol. 14, New Haven: Yale University Press. pp. 51-55.

PETo, A. 1969. Terrifying eyes: A visual forerunner. Psychoanalytic Study of the Child, 24: 179-212.

SIMmons, o. G. 1960. Ambivalence and the learning of drinking behavior in a Peruvian community. American Anthropologist, 62: 1018-27.

SPINDLER, G. M. 1961. Sociocultural and psychological processes in Menomini acculturation. In: Yehudi Cohen (ed.). Social Structure and Personality. New York: Holt Rinehart and Winston. pp. 430-54.

WITTKOWER, E. D. and H. H. WEIDMAN. 1968. Magical thought and the integration of psychoanalytic and anthropological theory. Transcultural Psychiatric Research Review, 5: 125-30. 